\title{
HOUSING VULNERABILITY FOR SENIORS IN LATVIA
}

\author{
Liga Rasnaca, Endija Rezgale-Straidoma \\ University of Latvia, Latvia \\ liga.rasnaca@lu.lv
}

\begin{abstract}
The study concentrates on housing vulnerability during the post-crisis period in Latvia and how it has impacted vulnerable groups, particularly seniors. Housing vulnerability includes objective and subjective factors. Seniors $65+$, especially those seniors who live alone are one of the vulnerable groups in sense of housing security. It could be characterized by parameters of housing quality and housing expenses adequacy. The EU policy examines perceptions of insecurity in few areas, including housing security and old-age income insecurity - of not having an adequate income in old age. The number of single senior 65+ households is increasing in both rural and urban areas. The study explores housing vulnerability for older persons - seniors $65+$, one of social groups in disadvantageous economic situation. Authors explore how housing vulnerability affects seniors, especially those who are over the age of $65+$ and are living alone. The challenging issues were construction of theoretical background integrating housing security during social changes in the post-crisis period with disadvantegous situation of seniors $65+$. The comparative quantitative approach is based on data from descriptive statistics. The research design is quantitative comparative analysis. To make a comparison, there were selected two groups: single seniors $65+$ and all households. The proposition is that in the post-crisis period housing vulnerability for seniors 65+ was decreasing, but differs from an average parameters of housing vulnerability for total population. The restriction of current study is analyses that covers only single seniors $65+$. The results show significant differences in housing quality and proportional housing maintanace expenditures between single seniors $65+$ and all households.
\end{abstract}

Key words: housing vulnerability, housing security, post-crisis period, seniors.

\section{Introduction}

Housing is necessary for every person, regardless of its age, occupation and affiliation to an ethnic or social group. The requirements for qualitative housing may vary in different climatic conditions, influenced by certain social standards and historically established traditions. Providing an adequate housing is a challenge for different societies. It is influenced by the level of public welfare, accepted social standards, as well as specific laws and regulations.

Providing an adequate un suitable quality housing is one of the biggest challenges facing today's society in both big cities and rural areas (Eurofond, 2016). To provide housing for vulnerable groups is particularly difficult.

Seniors are individuals who belong to vulnerable groups. The concept of a senior can be defined using different age limits. In this article, referring to the elderly, authors prefer the notion of a senior rather than an elderly person. Over the past decade, seniors in English have been less and less often called elderly people or elder, instead offering a better name for older persons, older people or seniors. It is related to the topicality of the concepts of human dignity and respect in the international agenda of social policy (SIforAGE, 2016). Seniors as a statistical group from the age of 65 have been used in European Union statistics (Eurostat) to link this limit to the retirement age in most EU countries (Eurostat, 2019). The vulnarable groups including seniors are groups that are exposed to new social risks in a welfare state moving to a postindustrial society. Social policy professor Peter TaylorGooby of the University of Kent emphasizes that the transition to a post-industrial society is the cornerstone of the lives of those who belong to vulnerable groups (Taylor- Gooby, 2004). The Latvian law 'On State Pensions' establish the age for granting of the pension from 62 to 65 years (according to Section 11(1) of the Law on State Pensions and Paragraph 81 of the transitional provisions of the mentioned Law).

The proportion of single senior of $65+$ households are increasing in post-crisis period in Latvia, in both rural and urban areas (CSB, 2019a).

Providing adequate quality housing for each person includes not only objective quality indicators (square meters, temperature, etc.), but also ideological and social support. The quality of housing is linked to other dimensions of quality of life (family life, personality development, social capital, etc.) as it is a place where they can be realized. The quality parameters and financial aspects are very important for older persons due to increased health and financial vulnerability.

The article will focus on the issues of housing vulnerability for seniors in Latvia in the post-crisis period (2010-2017). Insufficient housing security means vulnerability. In extreme situation it could be expressed as housing deprivation for seniors. The shelter services or institutional care are solutions for seniors who are coming into contact with extreem housing deprivation. The Law on Social Services and Social Assistance defines concepts: shelter, night shelter and long-term care institutions (LR Saeima, 2002) as social services and institutions, but seniors $65+$ are not the main target group for these services. The concept of housing has a dual 
meaning. This applies to housing functions as well as ownership and investment (Fahey \& Norris, 2010). Housing vulnerability for seniors is characterised by parameters of housing quality and availability (financial parameters, maintenance difficulties) in the post-crisis period cover changes in the housing system after the global financial and socio-economic crisis (Elsinga, 2015).

The article on housing vulnerability will first analyze the theoretical approaches to the understanding of housing and the concept of possible home vulnerability, then outline the methodology of empirical research and analyze statistical data. Theoretically, housing vulnerability can be analyzed in the context of common social uncertainty, previously unknown risks and global processes.

Vulnerability issues in the public are addressed by Ulrick Beck's concept of risk society and the Zigmunt Bauman's uncertainty century (Bauman, 2007). Beck highlights crises and conflicts in risk society. Lack of housing and the problems of home improvement can be linked to poverty, crises, social exclusion and risks to housing security (Beck, 1992). Bauman associates the rise of uncertainty and fear in society with the increase in the influence of global forces, as global forces seem to be 'force majeure' that cannot be resisted either by the individual or by the certain, especially the small state and society (Bauman, 2007).

The vulnerability of social groups is particularly acute as a result of the implementation of the neo-liberal policy of the late twentieth century. Neo-liberalism is a political philosophy that encourages individualism and market-based social and economic solutions while reducing government interference in the search for economic and social solutions. At a time when global change is demanding government interventions to mitigate environmental and socio-economic risks, an individual approach calls for government interference in decision-making and spatial planning processes. Governments have, to a certain extent, resigned from many national, regional and local housing issues. As a result, private players themselves have to deal with housing provision and quality issues. Such an approach promotes the perception of citizens as rational consumers who operate under conditions of access to information and are able to make the best choice. The social consequences are the diminishing influence of governments on housing policies at national and regional level. The contradiction of sustainable development is the demand for intervention in housing policy on the one hand, especially in improving the consequences of the crisis and the situation of vulnerable groups, and, on the other hand, the lack of appropriate instruments in the hands of governments as a result of the implementation of neo-liberal policies (Perkins \& Thorn, 2012). As a result of less targeted government action, it is almost impossible for governments to develop a socially sustainable housing policy, while maintaining housing policy support for the most vulnerable.

Obvious problems in obtaining housing rental rights and mortgages can stimulate higher demand for social housing, moving to another place of residence and, in extreme cases, even homelessness. The liberal approach emphasizes the avoidance of a stigmatizing approach to victimization, which could diminish the awareness of each individual's rights to housing. Sometimes the liberal approach even avoids the use of concepts such as 'underclass' 'poor elderly', preferring the notion of vulnerable groups or 'disadvantaged groups' (Spicker, 2011). Cumulative disadvantage can be facilitated by failure of public housing policy, non-addressing the needs of individual of certain groups (Zobena, 2018). This is particularly important when it comes to social housing policies, which are aimed at ensuring certain standards and addressing the problems of social groups in vulnerable situation. Without solving the problem, a housing policy promotes reproduction of inequality (Rugh, Albright, \& Massey, 2015). For example, without addressing the problems of denationalized tenants, neither they nor their family members can count on housing as property, seed capital for improving housing conditions. Citizens in poor quality housing may be at a higher risk of eviction because the new owners have an objective reason to demolish the house, make major repairs to it. Housing security means protecting against unexpected loss of home (eviction, relocation). If this happens, just follow the legitimate grounds and procedure (Payne \& Durand-Lasserve, 2012).

In the article on housing vulnerability as a basis for a theoretical concept, a sustainable approach is used as well as a concept of housing functionality as a basic need in the context of the post-crisis housing solutions in post-communist countries. Housing quality parameters, their inadequacy to household needs and standards in disparities in home improvement in countries, regions, and between different types of households, as well as financial insecurity (perception of the ability to pay for housing costs) may manifest in vulnerable situation in certain (individual) group, risk of deprivation of housing and even lead the extreme manifestation of housing deprivation homelessness.

The results of the empirical study provide answers to questions about changes in housing quality and deprivation, as well as other factors affecting social insecurity. The ultimate consequences of housing insecurity can be manifested in housing deprivation, which is brightly manifested in homelessness.

The aim of study is to explore how housing vulnerability affects single seniors $65+$ in the postcrises period. 
There have been serious studies of housing issues in Latvia during the post-crises period (Parsova \& Sidelska, 2017; Henilane, 2016), but these studies were not focused on housing vulnerability for single seniors. Previously some Latvian authors have studied housing deprivation, vulnerability, regional differences in housing quality (for example, Dobelniece \& Rasnaca, 2016; Rasnaca, 2017), but the special focus on seniors' housing vulnerability is an innovative element. Seniors housing vulnerability has been mentioned in Central Statistical Bureau (CBS) publications (CSB, 2016). There are not many scientific publications about housing vulnerability of seniors in Latvia. The study about single seniors $65+$ housing vulnerability discusses an innovative issue: up to now the topic has been rarely touched among social scientists in Latvia. The main tasks are: 1) to construct theoretical background based on ideas about a cumulative disadvantage and ideas of housing sustainability for seniors $65+$ as a vulnerable group in housing provision; 2) to construct methodological frame for analyses of statistics; 3) to analyse results of differentiating parameters characterising housing vulnerability.

The hypothesis of comparative study is that housing vulnerability parameters allow to substantiate single seniors $65+$ housing vulnerability considered as a disadvantaged group. To validate hypothesis, authors used sub-hypotheses:

1. Single senior $65+$ housing quality parameters (cold and hot water supply, sewerege) are worse than all households quality parameters and it is financial burden to them.

2. Single senior $65+$ housing maintenace expenditures are higher than for all households.

3. Single senior $65+$ subjective perception of housing maintenance expenditure (as a heavy burden) influence on the household finansial situation is worse that for all households.

\section{Materials and Methods}

The research design is a quantitative comparative study. Housing quality is a multi-dimensional phenomenon, including physical and social parameters. The indicators of seniors housing vulnerability included parameters of housing quality and financial expenditures of dwelling. Housing vulnerability for seniors is characterised by parameters of housing quality and availability (cold and hot water, sewerage, and size of dwelling; objective and subjective parameters on housing maintenance expenditures). The post-crisis period cover changes in the housing system after the global financial and socio-economic crisis. The global socio-economic crisis took place in the years 2008-2009 (Elsinga, 2015). Global time framework for crisis was 2007-2008/9. The beginning of the socio-economic crisis was slightly lugged in
Latvia, but it progressed rapidly. The international studies indicate that the post-crisis period began from 2010 (in political statements of Latvia, too).

In order to be able to explore how housing vulnerability affects single seniors $65+$, authors used data that were obtained from Central Statistical Bureau (CSB) of Latvia data bases. The years of explicit socio-economic crisis were 2008-2009 (Kajaks, 2013; Auziņa-Emsiņa, 2014). 'From early 2010 onwards, Latvia's main economic indicators finally began to show signs of improvement' (Kajaks, 2013). The beginning of the post-crisis period can be considered both 2010 (Åslund \& Dombrovskis, 2011) or 2011 (Eihmanis, 2013; Auzina-Emsina, 2014). Authors of the current study consider the necessity to include the year 2010 in the post-crisis period analysis for more complete display of housing vulnerability for single seniors $65+$. The time period that autors analysed the following data was eight post-crisis years and it indicates on statistical trends (EU-SILC, 2019; CSB, 2019). The post-crisis period was in 2010, 2011, 2012, 2013, 2014, 2015, 2016, and 2017. There is an insufficient data about housing for single seniors $65+$ living in both rural and urban areas.

To make a comparison, there were selected two groups: single seniors $65+$ and all households. First of all, authors analysed the statistical data on the the proportion of single seniors $65+$ households in urban and rural area. Moreover, data about an average size of dwelling in square meters per household member in the post-crisis period in Latvia were analysed. Furthermore, parameters on housing quality were analysed (dwelling supply with hot, cold water and sewerage). In addition, housing maintenance expenditure per one household and influence on household financial situation were analysed. This parameter characterizes single seniors' $65+$ subjective perception of housing maintenance expenditures.

Unlike statistical data where the particular target group is called single persons, authors of this article prefer to call this group single seniors, that way showing respect and dignity to them.

\section{Results and Discussion}

Although there are several studies conducted on household issues in Latvia, mainly they are focused on households policy analysis in context of quality of life. There are quite a few studies done on households property and ownership issues (Sidelska, 2013) and several studies done exploring households considering their financial aspect (Henilane, 2016), but one cannot find a research that specifically would be aimed to investigate housing vulnerability for seniors in Latvia.

According to CSB data, single seniors 65+ constituated $18.2 \%$ of urban households and $15.1 \%$ of rural households in Latvia. 
40

20

0

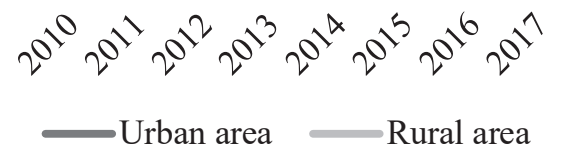

Figure 1. Proportion of single senior $(65+)$ households in the post-crises period in urban and rural area in 2010-2017 in Latvia (\%).

Source: authors' construction based on the data of Central Statistical Bureau of Latvia, 2019.

The proportion of single seniors $65+$ households are slightly increasing during the post-crises period (Figure 1). It is not a direct effect of crisis, but partly due to exuberate outwards migration flows during crisis (Mierina, 2015) and ageing proceses in society.

The increasing proportions of single senior $65+$ households in urban as well in rural area in Latvia could be described by ageing trend of Latvian population. Statistics show no evident differences between ageing trend in rural and urban area. The outward migration as the parallel process reinforces depopulation and housing size availability.

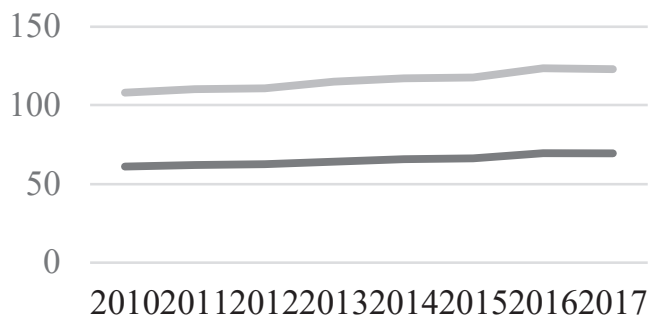

All household $\longrightarrow$ Single person $65+$

Figure 2. Average size of dwelling $\left(\mathrm{m}^{2}\right)$ per household member in the post-crises period in Latvia.

Source: authors' construction based on the data of Central Statistical Bureau of Latvia, Housing statistics, 2019.

Larger average size of dwelling space could be a positive factor of housing quality, but not for single seniors 65+. Larger dwelling space for seniors $65+$ in Latvia means larger finansial burden necessary to pay from small pensions. More important housing quality indicator for single seniors $65+$ is dwelling supply with different amenities. Seniors more often need medical and social care and better amenities could improve their life (SSE Riga, 2018).

Following data allows to analyse housing quality parameters: size of dwelling in $\mathrm{m}^{2}$, amenities: hot water and sewerage.

$$
\begin{aligned}
& 82.4-81.5-83-83.8-85.7-86-86.4-88.7 \\
& 86.6-86.8-87.5-88.2-88.8-89.5-90-91.4 \\
& 67.1-66.6-70-72.8-74.9-75.9-76.2-79.1 \\
& 76-72.5-78.2-80-81.5-83-83.8-84.4
\end{aligned}
$$

20102011201220132014201520162017

- - Sewerage: single person 65+

- - Sewerage: all households

- - Hot water: single person $65+$

- - Hot water supply: all households

Figure 3. Dwelling supply with different amenities in post-crises period (\%).

Source: authors' construction based on the data of Central Statistical Bureau of Latvia, Housing statistics, 2019.

First of all, the difference between single seniors $65+$ and all households supply with different amenities (cold water, hot water and sewerage) are minor, but seniors' dwelling supply are lower by $2-5 \%$. The most significant differences are in hot water supply (5.3\%). Moreover, the supply with all three amenities incerase for seniors as well as for all households during the post-crises period. Furthermore, one of ten seniors 65+ still live in dwelling without severage (WC) (12.3\%). Only $88.7 \%$ of all seniors $65+$ have sewerage in their dwelling and $79.1 \%$ have hot water. Each fifth single senior $65+$ still live without hot water in his dwelling (Figure 3). The proportion of single seniors 65+ living without basic amenities (hot water, WC) are ten times higher than in the EU (Eurostat, 2019a).

A very important indicator for housing vulnerability is financial availability - ability to pay housing expenditures.

Housing maintanance expenditure per one household has increased from 117.9 euro till 138 euro (all households) and from single seniors $65+$ from 78.6 euro till 89.7 euro during the post-crises period. The sum for housing maintanance could seem rather small, but authors are taking into account that more than $50 \%$ of all age pensioners recieve less than 300 euro per month, including more than 40000 persons with less than 200 euro per month (VSAA, 2019).

There are statistically (Chi-square $<0,05$ ) significant differences in housing maintanance expenditure per one household between all households and single person 65+ households (in 2017 13.5\% and $25.5 \%$ respectively) (Figure 4 ). The difference in housing maintanance expenditures are rather stable during the post-crises period (from $11.2 \%$ to $13.9 \%$ ). 
The single seniors $65+$ housing maintanance expenses are significantly higher than for all households. It could be understood as a sign for necessary changes in social housing policy.

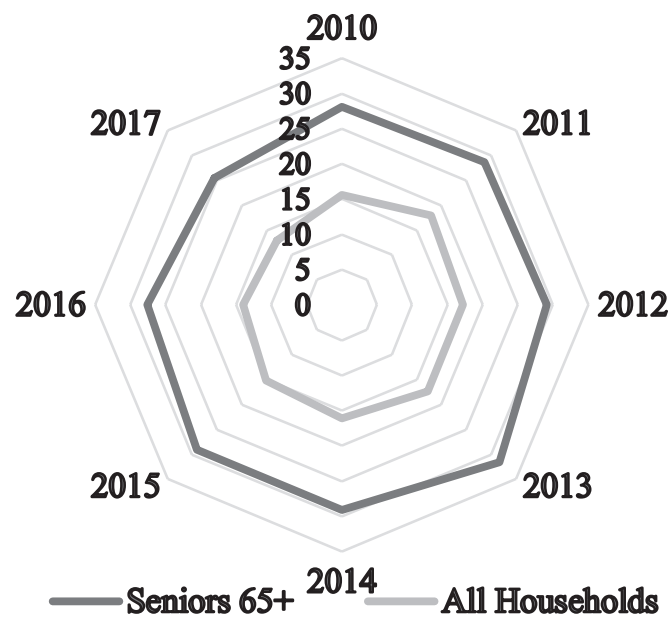

Figure 4. Housing maintenance expenditure as percentage of disposal income per one household 2010-2017.

Source: authors' construction based on the data of Central Statistical Bureau of Latvia, Housing statistics, 2019.

Housing maintanance expenditure influence on household financial situation is a subjective factor. It depends on subjective perception of difficulties to pay for housing and financial security.

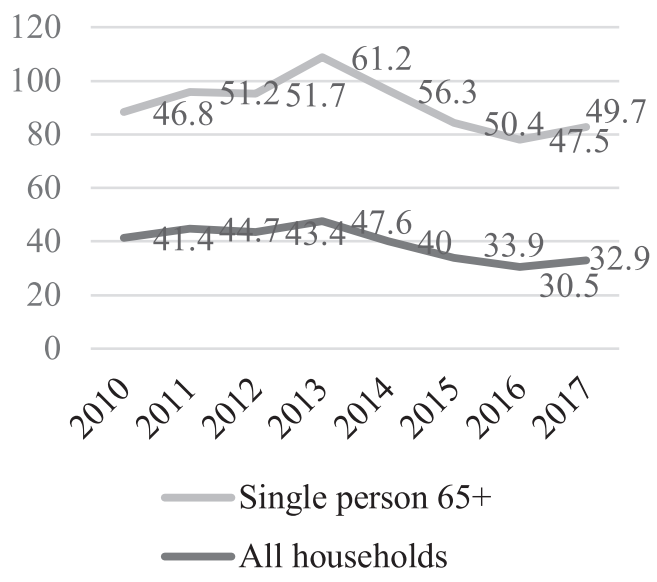

Figure 5. Housing maintenace expenditure (as 'a heavy burden') influence on household financial situation.

Source: authors' construction based on the data of Central Statistical Bureau of Latvia, Housing statistics, 2019.

First of all, overall perception of housing maintanance expenditures as 'a heavy burden' has decreased in the post-crises period in Latvia. Moreover, every third household reports about housing expenditure as 'a heavy burden' (32.9\%). Futhermore, almost every second single senior $65+$ expresses opinion that housing maintanance expenditure is a heavy burden for them (49.7\%) (CSB, 2019). In addition, the gap between all households expressed perception of housing maintanance expenditures as 'a heavy burden' and single seniors $65+$ joined this view have widened during the post-crises period. Finally, the proportion of single seniors 65+ who feel housing financial insecurity is very high - almost half of all single seniors $65+$. To sum up: a) it confirms that single seniors $65+$ is a vulnerable group, in a disadvantegous position compared with other househods; b) it is a signal for necessary changes in social housing policy. The data shows clear evidence about single seniors $65+$ as a vulnerable group in a disadvantegous housing situation. It is not only about urban households, because there is only a slight difference between urban and rural households percieved housing maintanace expenditure as 'a heavy burden'.

\section{Conclusions}

1. The aim of article is reached by exploring how the housing vulnerability affects single seniors $65+$ in the post-crisis period in Latvia. The objective and subjective factors were tested according to the available statistics. The quantitative comparative approach was used.

2. The housing vulnerability of single seniors $65+$ are expressed to be more significant in housing supply with the basic amenities than with the size of a dwelling. The data on a subjective perception of housing expenditures as 'a heavy burden' approves use of term 'a vulnerable group in a disadvantageous position' for single seniors $65+$ in Latvia. The housing deprivation level for single seniors $65+$ is significantly higher compared to all households in Latvia and (in housing deprivation) to households in the EU. The level of financial burden compared to all households is significantly higher.

3. Sustainability and uncertainty theories let us understand effects of socio-economic crisis on housing vulnerability. The single seniors $65+$ housing vulnerability is thematic novelty in the analysis of post-crisis proceses in Latvia.

4. Cumulative disadvantage could be observed analysing statistic data about housing maintanance expenditure. Almost every second single senior $65+$ percepts housing maintanance expenditures as 'a heavy burden'. Comparative trends in financial vulnerability do not show improvements in the group's position.

5. The study results allow to validate and conform hypotheses. The available statistics is insufficient for deeper analyses of single seniors $65+$ in rural/ urban comparision. 
6. The analysed data shows a necessity to review social housing policy to reduce housing vulnerability for seniors $65+$, especially for those who are single.

7. The main hypothesis is validated by subhypotheses:1) the housing quality parameters of single seniors $65+$ are worse than all households (except dwelling size); 2) single seniors' 65+ housing maintenance expenditures are relatively higher than for all households; 3) single seniors' $65+$ subjective perception of housing maintenance expenditure as 'a heavy burden'.
8. Methodological approach combining objective and subjective indicators and comparative approach for validation of hypotheses about housing vulnerability for one specific social group could be also applied for other social security risk groups.

\section{Acknowledgements}

This research has been generously supported by the University of Latvia project 'Public Health, Quality of Life and Sustainable Nation'.

\section{References}

1. Åslund, A., \& Dombrovskis, V. (2011). How Latvia Came through the Finacial Crisis. Washington: Columbia University Press.

2. Auzinna-Emsinga, A. (2014). Labour productivity and economic growth in the EU in post-crisis period. Economic and Management, 19(3), 233-240. DOI: 10.5755/j01.em.19.3.7819.

3. Beck, U. (1992). Risk Society. Towards a New Modernity. London: SAGE Publications.

4. Bauman, Z. (2007). Liquid Times: Living in an Age of Uncertainty. London: Polity.

5. Coats, D. (Ed.). (2011). Exiting from the Crisis: Towards a Model of More Equitable and Sustainable Growth. ETUI aisbl, Brussels. DOI: /2011/10.574/17.

6. CSB (2016). Vistrūcīgākie ir vientulie vecāka gadagājuma iedzīvotāji (The poorest are the lonely older people). Retrieved March 12, 2019, from http://www.csb.gov.lv/en/press_release/2269. (in Latvian)

7. CSB (2019). Social processes. Housing Conditions (EU-SILC). Retrieve-d March, 13, 2019, from http:// data1.csb.gov.lv/pxweb/en/sociala/sociala_majapst/MTG040.px/?rxid=a39c3f49-e95e-43e7-b4f0dce111b48ba1.

8. CSB (2019a). Social processes. Housholds by demographic type. Retrieved March 12, 2019, from https:// data.csb.gov.lv/pxweb/en/sociala/sociala_ms_sastavs/?tablelist=true\&rxid=edc9de06-5d99-4098-8.

9. Dobelniece, S., \& Rasnaca, L. (2016). Housing Security in Latvia: Regional Differences. In Proceedings of the 2016 International Conference: 'Economic Science for Rural Development' No. 43, 21-22 April, 2016, (pp. 25-32). Jelgava: LLU ESAF ISSN 2255-9930.

10. Eihmanis, E. (2013). Post-crisis Economic Governance in Latvia: the European Semester, the Balance-ofPayments Programme, and Euro Accession Convergence. Bruxselles: European Social Observatory. ISSN 1994-2893.

11. Elsinga, M. (2015). Changing housing systems and their potential impacts on homelessness. European Journal of Homelesness. 9(1), 15-36. ISSN 2030-2762.

12. Eurofound (2016). Inadequate housing in Europe: Costs and consequences. Luxembourg: Publications Office of the European Union. DOI: 10.2806/049107.

13. Eurostat. (2019). Population structure and ageing. Retrieved March 12, 2019, from https://ec.europa.eu/ eurostat/statistics-explained/index.php/Population_structure_and_ageing\#The_share_of_elderly_people_ continues to increas.

14. Eurostat (2019a). Housing deprivation. Retrieved April 1, 2019, from https://ec.europa.eu/eurostat/tgm/ table.do?tab=table\&init=1\&language $=$ en \&pcode $=$ tessi294\&plugin $=1$.

15. Fahey, T., \& Norris, M. (2010). Housing. In: Castles, F., Leibfried, S., Lewis, J., Obinger, H., \& Pierson, C. (Eds.), The Oxford Handbook of the Welfare State (pp. 479-480). Oxford, OUP. DOI: 10.1093/ oxfordhb/9780199579396.001.0001.

16. Henilane, I. (2016). Housing Concept and Analysis of Housing Classification. Baltic Journal of Real Estate Economics and Construction Management, 4, 168-179. DOI: 10.1515/bjreecm-2016-0013.

17. Kajaks, J. (2013). Study on the economic and social situation in the Baltic States. LATVIA . Bruxelles: European Economic and Social Committee. DOI: 10.2864/27766.

18. LR Saeima. (1995). Likums par valsts pensijām (Law on State Pensions). Latvijas Vēstnesis, 182 (465). (in Latvian)

19. LR Saeima (2002). Sociālo pakalpojumu un sociālās palīdzības likums (Law on Social Services and Social Assistance). Latvijas Vēstnesis, 168 (2743). (in Latvian) 
20. Mierina, I. (Ed.). (2015). Latvijas emigrantu kopienas: cerību diaspora (Emigrant Communities of Latvia: Diaspora of Hope). Rīga: Latvijas Universitātes aǵentūra 'Latvijas Univeristātes Filozofijas un sociolog̣ijas institūts', ISBN 978-9934-506-33-8. (in Latvian)

21. Parsova, V., \& Sidelska, A. (2017). Sustainability of dwellings in the context of their residents' opinion Conference: $16^{\text {th }}$ International Scientific Conference Engineering for Rural Development, 24-26 May, 2017, Jelgava, LLU. DOI: 10.22616/ERDev2017.16.N207.

22. Perkins, H., \& Thorn, D., (2012). Place, Identity \& Everyday Life in a Globalizing World. London: Palgrave Macmillian. ISBN 9780230575912.

23. Rasnaca, L. (2017). Housing quality and deprivation in post-crisis period: case study of Latvia. In Proceedings of the 2017 International Conference 'Economic science for rural development' No. 46, Jelgava, LLU ESAF, 27-28 April, 2017, (pp. 142-148). ISSN 2255-9930. DOI: 10.1080/13691457.2013.878316.

24. Rugh, J., Albright, L., \& Massey, D. (2015). Race, Space, and Cumulative Disadvantage: A Case Study of the Subprime Lending Collapse. Social Problems, 1, 62(2), 186-218. DOI: 10.1093/socpro/spv002.

25. Sidelska, A. (2013). The Role of Real Property in the Developmen of Dwellings. In Baltic Surveying 2013. Proceedings of the International Scientific Metodical Conference. Kaunas, Academia, pp. 141-146.

26. SSE Riga (2018). Inequality, a lack of caring for people and solidarity, but this can be changed! Retrieved April 1, 2019, from https://www.sseriga.edu/sites/default/files/inline-files/Results\%20of\%20Task\%20 Force $\% 20$ on $\% 20$ reducing\%20income $\% 20$ and $\% 20$ social $\% 20$ inequality.pdfAn evidence-based dream of a more equal Latvia

27. SIforAGE (2016). The Research Project SIforAGE Held a Session on Active and Healthy Aging at the European Parliament. Retrieved April 1, 2019, from http://www.ub.edu/web/ub/en/menu_eines/ noticies/2016/04/045.html.

28. Spicker, P. (2011). Stigma and social welfare. California: Croom Helm. ISBN 0-7099-3313-4.

29. Stockdale, A., \& MacLeod, M. (2013). Pre-retirement age migration to remote rural areas. Journal of Rural Studies, 32, 80-92. DOI: 10.1016/j.jrurstud.2013.04.009.

30. Taylor-Gooby, P. (2004). New Risks and Social Change. Retrieved April 1, 2019, from https://www. researchgate.net/publication/242612618_New_Risks_and_Social_Change. DOI: 10.1093/019926726X. 003.0001 .

31. VSAA. (2019). Budžets un statistika. Dati par piešķirto vecuma pensijas apjomu 2018.gada decembrī (Budget and Statistic. Data about amount of granted pensions in 2018). Retrieved April 1, 2019, from https://www.vsaa.gov.lv/budzets-un-statistika/statistika/?gid=6\&dates=2018-12-01. (in Latvian)

32. Zobena, A. (zin. red.) (2018). Inovatīvi risinājumi cel̦ā uz ilgtspēju: sabiedrība, ekonomika, vide. (Innovative Solutions for Sustainability: Society, Economy, Environment). Rīga: LU Akadēmiskais apgāds. ISBN 978-9934-18-309-6. (in Latvian) 